\title{
Synthesis, structural characterization, and anticancer activity of a monobenzyltin compound against MCF-7 breast cancer cells
}

This article was published in the following Dove Press journal:

Drug Design, Development and Therapy

23 November 2015

Number of times this article has been viewed

\author{
Somayeh Fani' \\ Behnam Kamalidehghan' \\ Kong Mun Lo \\ Najihah Mohd Hashim' \\ Kit May Chow ${ }^{2}$ \\ Fatemeh Ahmadipour' \\ 'Department of Pharmacy, Faculty of \\ Medicine, ${ }^{2}$ Department of Chemistry, \\ Faculty of Science, University of \\ Malaya, Kuala Lumpur, Malaysia
}

\begin{abstract}
A new monoorganotin Schiff base compound, [N-(3,5-dichloro-2-oxidobenzylidene)4-chlorobenzyhydrazidato]( $o$-methylbenzyl)aquatin(IV) chloride, (compound C1), was synthesized, and its structural features were investigated by spectroscopic techniques and single-crystal $\mathrm{X}$-ray diffractometry. Compound $\mathrm{C} 1$ was exposed to several human cancer cell lines, including breast adenocarcinoma cell lines MCF-7 and MDA-MB-231, ovarian adenocarcinoma cell lines Skov3 and Caov3, and prostate cancer cell line PC3, in order to examine its cytotoxic effect for different forms of cancer. Human hepatic cell line WRL-68 was used as a normal cell line. We concentrated on the MCF-7 cell line to detect possible underlying mechanism involvement of compound C1. 3-(4,5-dimethylthiazol-2-yl)-2,5-diphenyltetrazolium bromide (MTT) assay revealed the strongest cytotoxicity of compound $\mathrm{C} 1$ against MCF-7 cells, with a half maximal inhibitory concentration $\left(\mathrm{IC}_{50}\right)$ value of $2.5 \pm 0.50 \mu \mathrm{g} / \mathrm{mL}$ after 48 hours treatment. The $\mathrm{IC}_{50}$ value was $>30 \mu \mathrm{g} / \mathrm{mL}$ in WRL-68 cells. Induced antiproliferative activity of compound C1 for MCF-7 cells was further confirmed by lactate dehydrogenase, reactive oxygen species, acridine orange/ propidium iodide staining, and DNA fragmentation assays. A significant increase of lactate dehydrogenase release in treated cells was observed via fluorescence analysis. Luminescent analysis showed significant growth in intracellular reactive oxygen species production after treatment. Morphological changes of necrosis and early and late apoptosis stages were observed in treated cells after staining with acridine orange/propidium iodide. DNA fragmentation was observed as a characteristic of apoptosis in treated cells. Results of the present study obviously reveal potential cytotoxic effects of compound $\mathrm{C} 1$ against human breast cancer MCF-7 cells. Keywords: organotin derivatives, apoptosis, MCF-7 cells
\end{abstract}

\section{Introduction}

Organotin derivatives are one of the many non-platinum metal-based antitumor agents that appear to be very promising as potential drug candidates. ${ }^{1}$ In recent years, investigations have been carried out to test the cytotoxicity and antitumor activity of organotin (IV) compounds with Schiff bases. ${ }^{2,3}$ Organotin compounds are found to exhibit good to high cytotoxicity against various human cancer cell lines and are often more potent than cisplatin. ${ }^{4-8}$ In general, the biochemical activity of organotin compounds is influenced by the structure of the resulting compounds and the nature and number of organic groups bound to the tin center. ${ }^{9-15}$ In addition, the choice of coordinated ligand is also imperative in the biological effects of organotin compounds, such as solubility and bioavailability. A judicious choice of coordinating ligand not only can minimize the drawbacks, but also can enhance or modulate the activity of organotin compounds, ${ }^{16}$ as the ligand plays the key role in transporting and directing the molecule to the target site. ${ }^{17}$
Correspondence: Behnam Kamalidehghan Medical Genetics Department, National Institute of Genetic Engineering and Biotechnology (NIGEB), Tehran-Karaj Highway, Tehran, I4977|63 I6, Iran Tel +98 2I 4478730 I

Fax +98 21 44787399

Email behnam@um.edu.my 
Breast cancer is the most frequent form of cancer and the second most prominent cause of death in women worldwide. ${ }^{18}$ It is a malignant tumor that develops from breast tissue including ducts and lobule glands, which provide milk to ducts. ${ }^{19,20}$ Undesirable side effects of current cancer chemotherapeutic and multidrug resistance lead to an increasing interest toward investigating new anticancer agents, including synthetic compounds, with limited toxicity to normal tissue and less multidrug resistance of tumor cells. ${ }^{20,21}$

Numerous synthetic compounds have demonstrated significant anticancer effects toward breast cancer by targeting various molecular and cellular factors that are involved in the apoptosis mechanism. ${ }^{22,23}$ Apoptosis, or programmed cell death, acts as a part of normal cell growth in response to diverse extracellular or intracellular stimuli. ${ }^{24}$ It is vital for tissue homeostasis maintenance via eradicating cells that are no longer needed or are a threat to the organism. It is also necessary in controlling the balance between cell division and cell death, as imbalance between them can cause cancer. ${ }^{25}$ Defects in this regulated cell suicide process contribute to resistance of tumors, therefore understanding of apoptosis regulation is a key factor in additional promising anticancer drug discovery that can provoke death in cancer cells. ${ }^{26}$ Increasing evidence has supported that reactive oxygen species (ROS) play a central role in cell signaling and homeostasis. ${ }^{27}$ Extreme amounts of ROS can cause oxidative damage to lipids, proteins, and DNA, which results in cell death. ${ }^{28}$ Apoptotic cell death is discovered principally by ladder formation as a result of nuclear DNA degradation into nucleosomal units. ${ }^{29,30}$ The present work is designed to evaluate the cytotoxic effects and possible mechanisms for the antiproliferative property of compound $\mathrm{C} 1$ on human breast cancer MCF-7 cells. We present the apoptosis response of our novel drug by evaluating cell morphological changes, ROS level alteration, and DNA fragmentation.

\section{Materials and methods Materials}

The following commercial chemicals of reagent grade were used as supplied in the synthesis: 4-chlorobenzhydrazide, 2-hydroxy-3,5-dichlorobenzaldehyde, and 2-methylbenzyl chloride. The Schiff base ligand ( $N$-(3,5-dichloro-2oxidobenzylidene)-4-chlorobenzyhydrazide [L]) and $\operatorname{di}(o-$ methylbenzyl)tin dichloride were prepared according to methods in the literature. ${ }^{31}$ Methanol, which was used as the solvent in the preparation of the organotin compounds, was procured commercially and was dried over molecular sieve prior to use.

\section{Physical measurements}

The melting points of the benzyltin compound $\mathrm{C} 1$ were determined on an electrothermal melting point apparatus and were uncorrected. ${ }^{1} \mathrm{H},{ }^{13} \mathrm{C}$, and ${ }^{119} \mathrm{Sn}$ nuclear magnetic resonance (NMR) spectra were measured in dimethyl sulfoxide (DMSO) $-\mathrm{d}_{6}$ at ambient temperature on a JEOL Lambda 400 FT-NMR and a JEOL JNM GX-270 FT-NMR System spectrometer operating at $400.14 \mathrm{MHz}$ for ${ }^{1} \mathrm{H}$ and 100.63 $\mathrm{MHz}$ for ${ }^{13} \mathrm{C}$ NMR. The infrared (IR) spectra were recorded in the range of 4,000-400 $\mathrm{cm}^{-1}$ by using a PerkinElmer 2000 FTIR (fourier transform infrared) spectrophotometer. Elemental analysis was performed in the in-house microanalytical laboratory using a PerkinElmer EA2400 CHNS Elemental Analyzer. Single-crystal X-ray data collection was carried out at $100 \mathrm{~K}$ on a Bruker SMART APEXII $\mathrm{CCD}$ diffractometer using graphite-monochromated $\mathrm{MoK} \alpha$ $(\lambda=0.71073 \AA$ ) radiation. The crystal structure was solved by direct methods and refined using the full-matrix leastsquares procedures on $F^{2}$ using the SHELX-97 program. ${ }^{32}$ The dataset was corrected for absorption effects based on multiple scans. Non-hydrogen atoms were refined with anisotropic displacement parameters. The positions of hydrogen atoms were calculated and were included in the structure factor calculations. The molecular graphics were drawn using the XSEED plotting program. ${ }^{33}$

Crystallographic data for $N$-(3,5-dichloro-2-oxido benzylidene)-4-chlorobenzyhydrazidato]( $o$-methylbenzyl) aquatin(IV) chloride (compound $\mathrm{C} 1$ ) have been deposited at the Cambridge Crystallographic Data Centre with the deposition number CCDC1058348. These data can be obtained free of charge via http://www.ccdc.cam.ac.uk/conts/retrieving. html, or from the Cambridge Crystallographic Data Centre, 12 Union Road, Cambridge CB2 1EZ, UK; fax: +44 1223 336 033; or email: deposit@ccdc.cam.ac.uk.

\section{Synthesis of [N-(3,5-dichloro- 2-oxidobenzylidene)-4- chlorobenzyhydrazidato] (o-methylbenzyl)-aquatin(IV) chloride, CI}

$0.40 \mathrm{~g}(1.0 \mathrm{mmol})$ of di(o-methylbenzyl)tin dichloride in $5 \mathrm{~mL}$ of methanol was added to $25 \mathrm{~mL}$ of a hot stirring methanolic solution of $\mathrm{N}$-(3,5-dichloro-2-oxidobenzylidene)4-chlorobenzyhydrazide, L $(0.35 \mathrm{~g}, 1.0 \mathrm{mmol})$. The solution mixture was refluxed for 3.5 hours. The resulting solution was then filtered and allowed to stand at room temperature, during which yellow crystals were formed. The product was filtered, washed with methanol, and dried in air. Yield: $0.30 \mathrm{~g}$, $47 \%$; melting point $170^{\circ} \mathrm{C}-172^{\circ} \mathrm{C}$. Analysis calculated for $\mathrm{C}_{22} \mathrm{H}_{18} \mathrm{Cl}_{4} \mathrm{~N}_{2} \mathrm{O}_{3} \mathrm{Sn}$ : C, 42.69; H, 2.93; N, 4.53\%. Found: C, 
42.73; H, 2.78; N, 4.10\%. Infrared (KBr/ $\left.\mathrm{cm}^{-1}\right): 1,532 v(\mathrm{C}-\mathrm{O})$, $1,612 v(\mathrm{C}=\mathrm{N}) .{ }^{1} \mathrm{H}$ NMR (DMSO-d, ppm, [J] Hz): $\delta 8.08(\mathrm{dd}$ [8.0, 2.3], 2H, H1, and H4), 7.70 (dd [8.0, 2.3], 2H, H2, and H5), $\delta 8.89(\mathrm{~s}, 1 \mathrm{H},-\underline{\mathrm{HC}}=\mathrm{N}), \delta 7.59-7.61(\mathrm{~m}, 2 \mathrm{H}, \mathrm{H} 13$, and $\mathrm{H} 15), \delta 3.14$ (s, 2H, Sn-C $\left.\underline{H}_{2}, \mathrm{~J}\left({ }^{119} \mathrm{Sn}^{1} \mathrm{H}\right)[37.3]\right), \delta 7.05-7.34$ (m, 4H, H17-H20), 2.44-2.47 (m, 3H, H22), $\delta 3.41$ (s, $\mathrm{H}_{2} \mathrm{O}$ ). ${ }^{13} \mathrm{C}$ NMR (DMSO-d, ppm, [J] Hz): $\delta 129.1,128.8,135.9$, $132.0(\mathrm{C} 1-\mathrm{C} 6), \delta 166.0(\mathrm{~N}-\underline{\mathrm{C}}-\mathrm{O}), \delta 158.7(-\mathrm{HC}=\mathrm{N}), \delta 119.1$, $156.6,120.4,132.9,125.3,129.6(\mathrm{C} 9-\mathrm{C} 14), \delta 33.8\left(\mathrm{Sn}_{-} \mathrm{CH}_{2}\right)$, $\delta 20.0,136.7,136.4,131.3,122.6,125.9,130.0$ (C17-C22).

${ }^{119} \mathrm{Sn}$ NMR (DMSO-d, ppm): $\delta-488.2$.

\section{Cell lines and cell culture}

Ovarian carcinoma cells (Skov3 and Caov3) were a gift from Dr Najihah Mohd Hashim, Department of Pharmacy, Faculty of Medicine, University of Malaya (Kuala Lumpur, Malaysia). Different cancer cell lines (MCF-7, MDA-MB231, PC3, Caov3, Skov3) from the ATCC and normal cells (WRL-68) from ATCC, were obtained from the Special Medical Center (Tehran, Iran), and the Medical Ethics Committee of the Special Medical Center specifically approved breast cancer cell lines for this study (approval number AC-39-2234). Cells were seeded in $25 \mathrm{~cm}^{2}$ or $75 \mathrm{~cm}^{2}$ culture flasks and cultured in Roswell Park Memorial Institute (RPMI)-1640 medium that was supplemented with 10\% fetal bovine serum and $1 \%$ penicillin streptomycin at $37^{\circ} \mathrm{C}$ in a humidified atmosphere of $5 \% \mathrm{CO}_{2}$.

\section{MTT cell viability assay}

Viability assay for the cell lines (MCF-7, MDA-MB-231, Skov3, Caov3, PC3, and WRL-68) was done using 3-(4,5dimethylthiazol-2-yl)-2,5-diphenyltetrazolium bromide (MTT) assay. Cells were seeded into 96-well culture plates at a density of $1 \times 10^{4}$ cells/well and allowed to attach. After 24 hours, cells were treated with different concentrations of compound $\mathrm{C} 1$, ranging from $100 \mu \mathrm{g} / \mathrm{mL}$ to $1.25 \mu \mathrm{g} / \mathrm{mL}$, and incubated at $37^{\circ} \mathrm{C}$ in $5 \% \mathrm{CO}_{2}$ for 24,48 , and 72 hours. Afterward, $20 \mu \mathrm{L}$ of MTT was added to each well, and the plates were further incubated in the same conditions for 2 hours. After incubation, the solution in each well was removed, and $100 \mu \mathrm{L}$ DMSO was added into the wells to solubilize the produced formazan. The last row of wells were used as negative controls, to which only culture medium was added. The cytotoxic effect of cisplatin was examined against MCF-7 cells as positive control. Each concentration of the compound was tested in triplicate. A microplate reader was used to measure absorbance at $570 \mathrm{~nm}$ with a reference wavelength of $630 \mathrm{~nm}$. Cell viability was stated as percentage of the value for control after 48 hours' exposure to compound
C1. The concentration of compound with $50 \%$ cell growth inhibition was expressed as the half maximal inhibitory concentration $\left(\mathrm{IC}_{50}\right)$ value.

\section{$\mathrm{LDH}$ assay}

The growth inhibitive effect of compound C1 was further investigated through measuring lactate dehydrogenase (LDH) leakage into the culture medium. Treated MCF-7 cells with different concentrations of compound $\mathrm{C} 1$ and $2 \%$ Triton X-100 (positive control) were incubated for 24 and 48 hours. Afterward, the media were collected and centrifuged at 3,000 rpm for 5 minutes, and the supernatants were transferred into a new 96-well plate. One hundred microliters of the LDH reaction was loaded into each well and incubated for 30 minutes at room temperature. Lastly, by means of a Tecan Infinite ${ }^{\circledR}$ 200 pro (Tecan, Männedorf, Switzerland) microplate reader, the absorbance was measured at $490 \mathrm{~nm}$. The LDH activity in treated and untreated cells was determined by the volume of formazan salt generation and intensity of red color. The LDH release level in cells treated with compounds was expressed as a percentage of the positive control.

\section{Acridine orange/propidium iodide double staining}

Apoptosis was examined by staining with acridine orange (AO)/propidium iodide (PI) dye. Briefly, MCF-7 cells at a density of $1 \times 10^{6}$ in $25 \mathrm{~cm}^{2}$ culture flasks were treated with an $\mathrm{IC}_{50}$ of compound $\mathrm{C} 1$ and incubated in an atmosphere of $5 \% \mathrm{CO}_{2}$ at $37^{\circ} \mathrm{C}$ for 24 and 48 hours. Untreated cells were considered as a negative control. After incubation, the cells were centrifuged at 1,800 rpm for 5 minutes. Following the supernatant discarding, cells were washed twice with phosphate-buffered saline (PBS) in order to eliminate medium. Afterward, pellet cells were suspended in $10 \mu \mathrm{g} / \mathrm{mL}$ of a $1: 1$ AO/PI mixture comprising $10 \mu \mathrm{g} / \mathrm{mL}$ AO and $10 \mu \mathrm{g} / \mathrm{mL}$ PI (dissolved in PBS). The morphological changes were detected and photographed using a fluorescence microscope (Zeiss Axioskop 2 plus; Carl Zeiss Meditec AG, Jena, Germany). Green-colored cells specify viable and early apoptotic cells with intact nuclei and condensed nuclei, respectively, and red fluorescence indicates late apoptosis and necrosis, consisting of condensed and intact chromatin, respectively.

\section{ROS assay}

The intracellular ROS creation was assessed using $2^{\prime}, 7^{\prime}$ dichlorofluorescein diacetate (DCFH-DA). According to protocol, $5 \mathrm{mM}$ DCFH-DA stock solution was prepared through dissolving dye in $2.5 \mathrm{~mL}$ DMSO. This solution was diluted with PBS to prepare a $5 \mu \mathrm{M}$ working solution. 
Cells were grown onto 96-well transparent culture plates at a concentration of $1 \times 10^{4}$ cells/well and treated with different concentrations of compound $\mathrm{C} 1$ for 24 and 48 hours. The last two rows were used as positive control (treated with $\mathrm{H}_{2} \mathrm{O}_{2}, 1 \mathrm{mM}$ ) and negative control (untreated), respectively. After treatment, $50 \mu \mathrm{L}$ of DCFH-DA working solution was added to each well and incubated at $37^{\circ} \mathrm{C}$ for 30 minutes. Following that, formaldehyde $16 \%$ was used to fix cells for 10-15 minutes and then the plate was washed with PBS three times. Fluorescence intensity was determined using a fluorescence microplate reader with an excitation wavelength of 485 and emission wavelength of $530 \mathrm{~nm}$.

\section{DNA laddering assay}

In brief, $1 \times 10^{6} \mathrm{MCF}-7$ cells were grown in $25 \mathrm{~mL}$ culture flasks and treated with compound $\mathrm{C} 1$ at $\mathrm{IC}_{50}$ for 24,48 , and 72 hours. The same numbers of untreated cells were used as negative control. Next, pellet cells were collected by centrifugation (1,000 rpm, 5 minutes). Supernatant was discarded and the pellet part was used to isolate apoptotic DNA according to the procedures in the Suicide Track ${ }^{\mathrm{TM}}$ DNA Ladder Isolation Kit (catalog number AM41; Calbiochem, San Diego, CA, USA). The extracted DNA was analyzed by electrophoresis on a $1.5 \%$ agarose gel. Then, $21 \mu \mathrm{L}$ of samples was mixed in $5 \mu \mathrm{L}$ loading dye and loaded onto the gel before running at 50 constant volts. The gel was visualized using a transilluminator after staining with GelRed Nucleic Acid Gel Stain.

\section{Statistical analysis}

Data were presented as mean \pm standard deviation of three individual experiments. Statistical analysis was performed by a one-way ANOVA analysis by means of the Prism statistical software package (GraphPad Software, Inc., La Jolla, CA, USA). ${ }^{*} P<0.05$ was considered statistically significant.

\section{Results}

\section{Synthetic aspect}

The condensation reaction of 4-chlorobenzhydrazide with 3,5-dichlorosalicylaldehyde yielded the ligand $N$-(3,5dichloro-2-oxidobenzylidene)-4-chlorobenzyhydrazide (L), which is a yellow crystalline solid. Subsequent reaction of ligand L with di(o-methylbenzyl)tin dichloride gave the monobenzyltin Schiff base compound C1 (Figure 1). The melting point; elemental analytical data; ${ }^{1} \mathrm{H},{ }^{13} \mathrm{C}$, and ${ }^{119}$ Sn NMR chemical shifts; and IR stretching frequencies of selected functional groups are presented in the "Materials and methods" section. The molecular structure, which was determined by single X-ray diffraction, is depicted in Figure 2, while its crystal packing showing

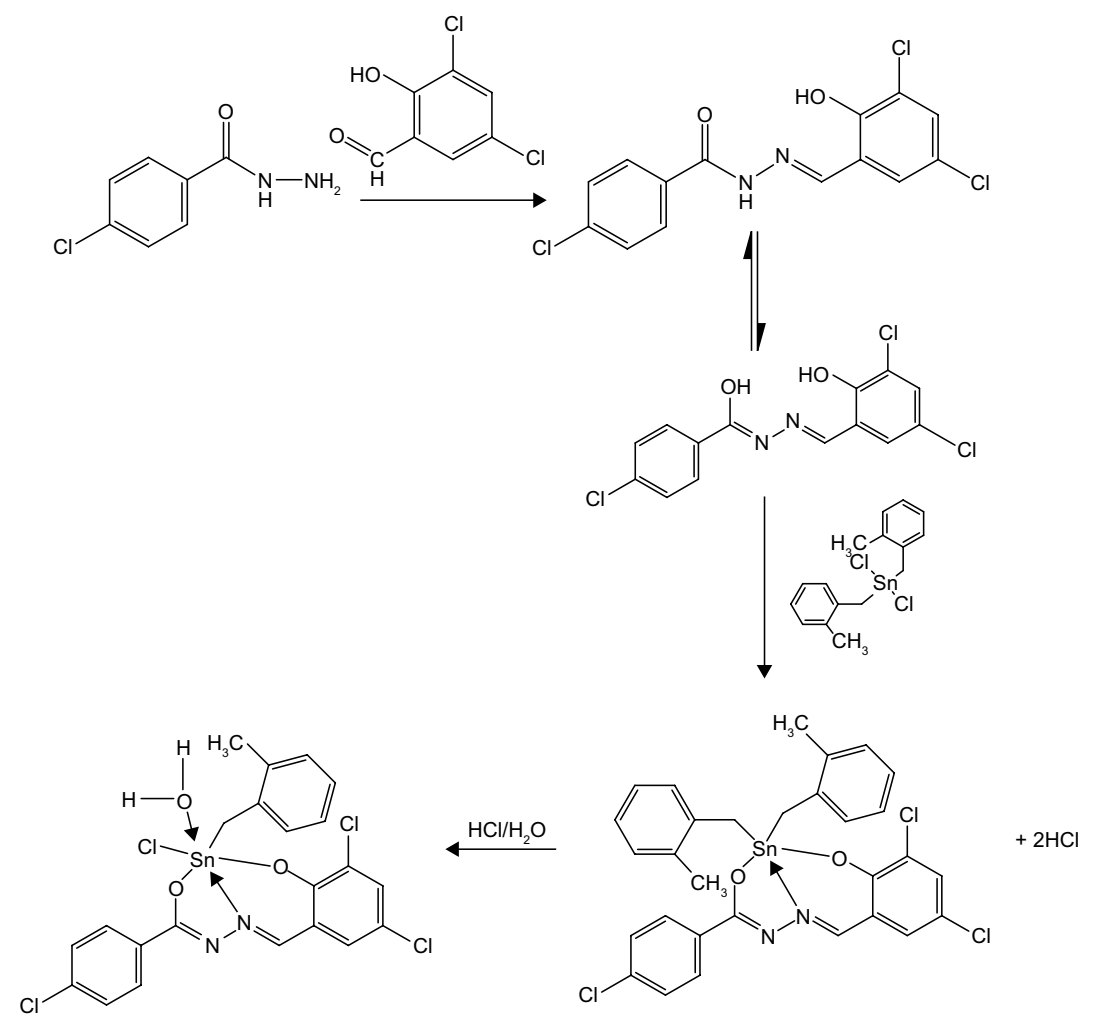

Figure I Synthetic route for benzyltin compound $\mathrm{Cl}$.

Abbreviation: $\mathrm{CI}$, compound I [N-(3,5-dichloro-2-oxidobenzylidene)-4-chlorobenzyhydrazidato](o-methylbenzyl)aquatin(IV) chloride. 


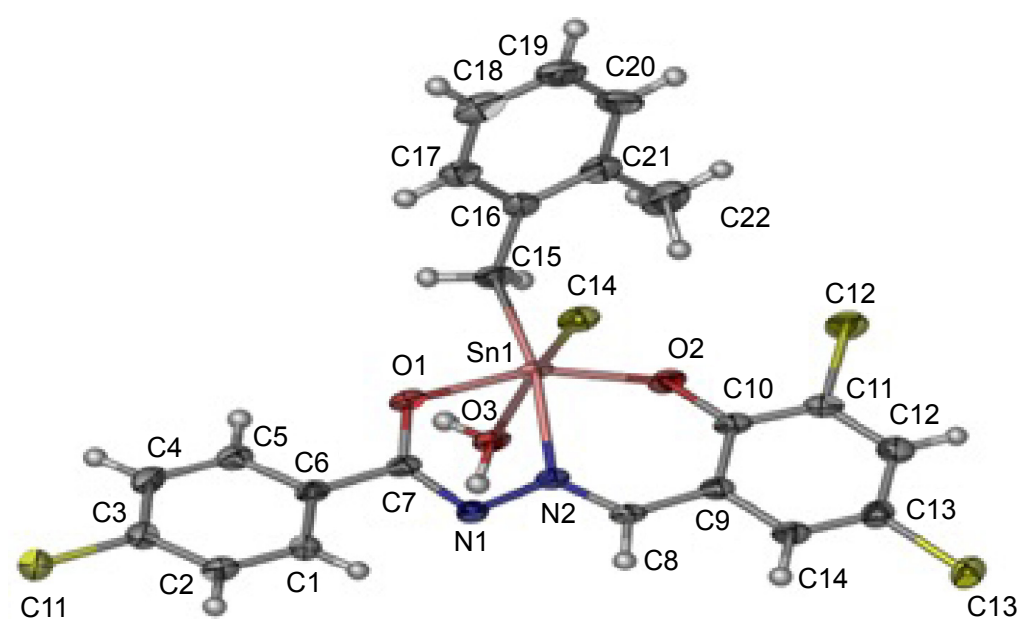

Figure 2 Molecular structure of compound I [N-(3,5-dichloro-2-oxidobenzylidene)-4-chlorobenzyhydrazidato](o-methylbenzyl)aquatin(IV) chloride with numbering scheme.

Note: Ellipsoids are drawn at $50 \%$ probability level.

the hydrogen-bonding interaction is presented in Figure 3. Tables 1-3 list the crystallographic data, bond distances and bond angles, and hydrogen-bond parameters of the compound, respectively.

\section{Determination of cell viability}

In order to determine whether compound $\mathrm{C} 1$ has different antiproliferative activity against different cancerous cell lines, the cytotoxicity assay (MTT) was performed for various cell lines, including MCF-7, MDA-MB-231, Skov3, Caov3, PC3, and WRL-68. The antiproliferative activity of cisplatin was also assessed as a positive control for the MCF-7 cell line. As shown in Table 4, after 48 hours' treatment, compound $\mathrm{C} 1$ displayed strong growth inhibition

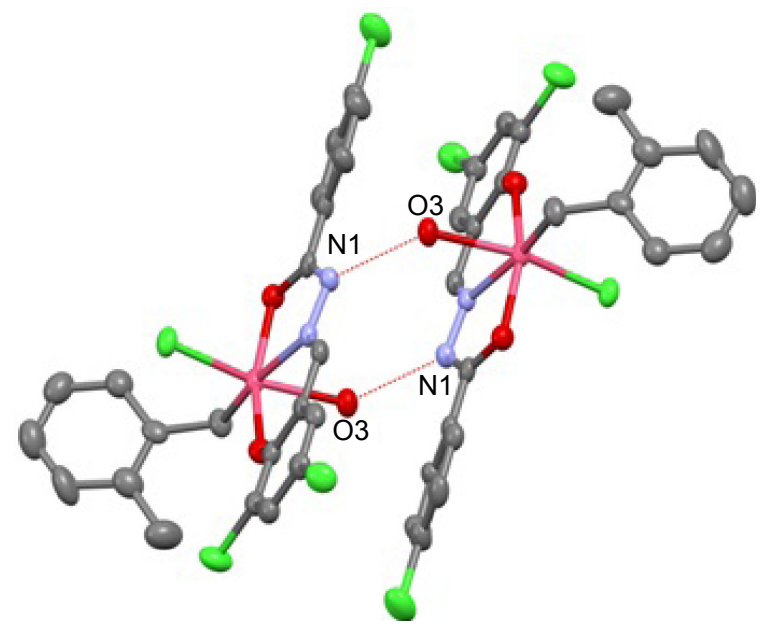

Figure 3 Packing diagram of $\mathrm{Cl}$, showing hydrogen-bond interaction.

Abbreviation: $\mathrm{Cl}$, compound I [N-(3,5-dichloro-2-oxidobenzylidene)-4-chlorobenzyhydrazidato](o-methylbenzyl)aquatin(IV) chloride; NI, nitrogen atom I; O3, oxygen atom 3. properties, with $\mathrm{IC}_{50}$ ranging from 2.5 to $8 \mu \mathrm{g} / \mathrm{mL}$, toward all five cancer cell lines. The $\mathrm{IC}_{50}$ value of cisplatin on $\mathrm{MCF}-7$ cells was lower compared to compound $\mathrm{C} 1$, at 1 and $2.5 \mu \mathrm{g}$ / $\mathrm{mL}$, respectively. The $\mathrm{IC}_{50}$ value for WRL-68 normal hepatic cells $(>30 \mu \mathrm{g} / \mathrm{mL})$ indicates a selective cytotoxic activity of compound $\mathrm{C} 1$ for tumor cells (Figure 4).

Table I Crystallographic data for compound CI

\begin{tabular}{|c|c|}
\hline Crystal data & $\mathrm{Cl}$ \\
\hline Empirical formula & $\mathrm{C}_{22} \mathrm{H}_{18} \mathrm{Cl}_{4} \mathrm{~N}_{2} \mathrm{O}_{3} \mathrm{Sn}_{1}$ \\
\hline Formula weight, $M_{r}$ & 618.87 \\
\hline Crystal system & Monoclinic \\
\hline Space group & $P 2 / C$ \\
\hline \multicolumn{2}{|l|}{ Unit cell dimensions } \\
\hline$a(\AA)$ & $12.5753(4)$ \\
\hline$b(\AA)$ & $|4.6| 6 \mid(4)$ \\
\hline$c(\AA)$ & $12.7893(4)$ \\
\hline$\alpha\left(^{\circ}\right)$ & 90 \\
\hline$\beta\left({ }^{\circ}\right)$ & $96.737(2)$ \\
\hline$\gamma\left(\left(^{\circ}\right)\right.$ & 90 \\
\hline$V\left(\AA^{3}\right)$ & $2,334.47(12)$ \\
\hline $\mathrm{Z}$ & 4 \\
\hline Calculated density, $D_{x}\left(\mathrm{Mg} \mathrm{m}^{-3}\right)$ & 1.761 \\
\hline Absorption coefficient, $\mu\left(\mathrm{mm}^{-1}\right)$ & 1.580 \\
\hline$\theta$ range $\left({ }^{\circ}\right)$ for data collection & 1.63 to 26.50 \\
\hline \multirow[t]{2}{*}{ Reflections collected/unique } & $19,554 / 4,835$ \\
\hline & {$\left[R_{\mathrm{int}}=0.0395\right]$} \\
\hline \multirow[t]{2}{*}{ Maximum and minimum transmission } & 0.8580 and \\
\hline & 0.7428 \\
\hline Total data/restrains/parameters & $4,835 / 0 / 291$ \\
\hline Goodness of fit on $F^{2}, S$ & 1.098 \\
\hline \multirow[t]{2}{*}{ Final $R$ indices $[I>2 \sigma(l)]$} & $\mathrm{R}_{1}=0.0367$ \\
\hline & $\mathrm{wR}_{2}=0.0834$ \\
\hline \multirow[t]{2}{*}{$\mathrm{R}$ indices (all data) } & $\mathrm{R}_{\mathrm{I}}=0.0564$ \\
\hline & $\mathrm{wR}_{2}=0.0966$ \\
\hline$\Delta \rho_{\max } / \Delta \rho_{\min }\left(\mathrm{e} \AA^{-3}\right)$ & $1.004 /-0.714$ \\
\hline
\end{tabular}

Note: Data shown in parentheses are standard deviation.

Abbreviation: $\mathrm{Cl}$, compound I [N-(3,5-dichloro-2-oxidobenzylidene)-4-chlorobenzyhydrazidato](o-methylbenzyl)aquatin(IV) chloride. 
Table 2 Selected bond lengths $(\AA)$ and angles $\left(^{\circ}\right)$ of $\mathrm{Cl}$

\begin{tabular}{|c|c|}
\hline Bond & Results \\
\hline Bond (length) & Length \\
\hline $\mathrm{OI}-\mathrm{C7}$ & $1.295(5)$ \\
\hline $\mathrm{NI}-\mathrm{C7}$ & $1.315(5)$ \\
\hline $\mathrm{N} 2-\mathrm{C} 8$ & I. 289 (5) \\
\hline $\mathrm{O} 2-\mathrm{ClO}$ & $\mathrm{I} .328(5)$ \\
\hline SnI-OI & $2.098(3)$ \\
\hline $\mathrm{SnI}-\mathrm{O} 2$ & $2.032(3)$ \\
\hline $\mathrm{SnI}-\mathrm{O} 3$ & $2.280(3)$ \\
\hline SnI-CI5 & 2.143 (4) \\
\hline SnI-N2 & $2.183(3)$ \\
\hline $\mathrm{SnI}-\mathrm{Cl} 4$ & 2.4475 (II) \\
\hline Bond (angle) & Angle \\
\hline OI-SnI-N2 & $73.77(12)$ \\
\hline O2-SnI-N2 & $84.83(13)$ \\
\hline OI-SnI-CI5 & $98.99(16)$ \\
\hline O2-SnI-CI5 & $101.01(16)$ \\
\hline O2-SnI-OI & 158.19 (II) \\
\hline $\mathrm{O} 2-\mathrm{SnI}-\mathrm{O} 3$ & $88.78(12)$ \\
\hline CI5-SnI-N2 & $166.01(16)$ \\
\hline $\mathrm{N} 2-\mathrm{SnI}-\mathrm{Cl} 4$ & $88.18(9)$ \\
\hline O3-SnI-Cl4 & $167.55(8)$ \\
\hline
\end{tabular}

Note: Data shown in parentheses are standard deviation.

Abbreviation: $\mathrm{Cl}$, compound I [N-(3,5-dichloro-2-oxidobenzylidene)-4-chlorobenzyhydrazidato] (o-methylbenzyl)aquatin(IV) chloride.

\section{Compound $\mathrm{Cl}$-induced $\mathrm{LDH}$ release}

LDH is a cytosolic enzyme which oxidizes L-lactate to pyruvate. Leakage of $\mathrm{LDH}$ from cytoplasm in the medium is an indicator that there is change in plasma membrane permeability or incidence of apoptosis or necrosis. To investigate the impact of benzyltin compound $\mathrm{C} 1$ on LDH activity, MCF-7 cells were treated with different concentrations of compound for a period of 24 and 48 hours. The results demonstrate a significant induction of $\mathrm{LDH}$ rise in cells treated with $\mathrm{IC}_{50}$ and higher concentrations of compound $\mathrm{C} 1$ after 48 hours' treatment $(P<0.05)$. Cells treated for 24 hours showed similar behavior at concentrations of 5 and $10 \mu \mathrm{g} / \mathrm{mL}$. However, an increase in LDH release was not statistically significant in cells treated with compound $\mathrm{C} 1$ for 24 hours at $\mathrm{IC}_{50}$ (Figure 5).

\section{Quantification of apoptosis using AO/PI double staining}

The morphological changes that relate to apoptosis and cell death induced by compound $\mathrm{C} 1$ were analyzed employing

Table 3 Hydrogen-bond geometry for $\mathrm{Cl}$

\begin{tabular}{llllll}
\hline Compound D-H...A & d(D-H) & d(H...A) & d(D...A) & $<$ (DHA) \\
\hline Cl & O3-H3B...N2\#I & 0.87 & 2.82 & $3.676(5)$ & 167.8 \\
& O3-H3A...Cl4\#2 & 0.87 & 2.48 & $3.294(3)$ & 154.7 \\
\hline
\end{tabular}

Notes: Data shown in parentheses are standard deviation. Symmetry transformations used to generate equivalent atoms: \#I $-x+1,-y+2,-z+2 ; \# 2 x,-y+3 / 2, z+1 / 2$. Abbreviation: $\mathrm{Cl}$, compound I [N-(3,5-dichloro-2-oxidobenzylidene)-4-chlorobenzyhydrazidato] (o-methylbenzyl)aquatin(IV) chloride.
Table $4 I_{50}$ of compound $\mathrm{Cl}$ against MCF-7, MDA-MB-23I, Skov3, Caov3, PC3, and WRL-68 cell lines

\begin{tabular}{lll}
\hline Cell line & \multicolumn{1}{l}{$\mathbf{I C}_{\mathbf{5 0}} \pm \mathbf{S D}(\mu \mathrm{g} / \mathbf{m L})$} \\
\cline { 2 - 3 } & $\mathbf{2 4}$ hours & $\mathbf{4 8}$ hours \\
\hline CI-treated MCF-7 & $3.5 \pm 0.50$ & $2.5 \pm 0.50$ \\
Cisplatin-treated MCF-7 & $1.5 \pm 0.39$ & $\mathrm{I} \pm 0.45$ \\
MDA-MB-23I & $3.5 \pm 0.50$ & $2.5 \pm 0.50$ \\
Skov3 & $6.5 \pm 0.26$ & $6.5 \pm 0.56$ \\
Caov3 & $8.5 \pm 0.50$ & $8 \pm 0.50$ \\
PC3 & $6 \pm 0.49$ & $6 \pm 0.35$ \\
WRL-68 & $38 \pm 0.32$ & $38 \pm 0.38$ \\
\hline
\end{tabular}

Abbreviations: $\mathrm{Cl}$, compound I [N-(3,5-dichloro-2-oxidobenzylidene)-4-chlorobenzyhydrazidato] (o-methylbenzyl)aquatin(IV) chloride; $\mathrm{IC}_{50}$, half maximal inhibitory concentration; SD, standard deviation.

AO/PI fluorescence microscopy double staining after treatment for 24 and 48 hours. Figure $6 \mathrm{~A}$ and B show the morphological features of different stages of cell death after 24 and 48 hours' treatment, respectively. The untreated cells were observed with a green, normal, and large nuclear structure and were AO (+) and PI (-) (Figure 6C). When AO and PI, interpolating nucleic acid dyes, bind to DNA, they release green and orange fluorescence, respectively. Viable cells and cells at an early stage of apoptosis stain with AO, while cells at a late stage of apoptosis and necrotic cells stain with both AO and PI. Early apoptotic cells with a green condensed nuclear structure (AO [+] and PI [-]); cells at a late stage of apoptosis with a condensed nuclear structure and reddish-orange color $(\mathrm{AO}[+]$ and $\mathrm{PI}[+])$; and necrotic red, swollen, enlarged cells with nuclei $(\mathrm{AO}[+]$ and $\mathrm{PI}[+])$ are shown in Figure 6A and B. The percentages of viable, early apoptotic, late apoptotic, and necrotic cells were quantified in more than 200 treated MCF-7 cells. As shown in Figure 6D,

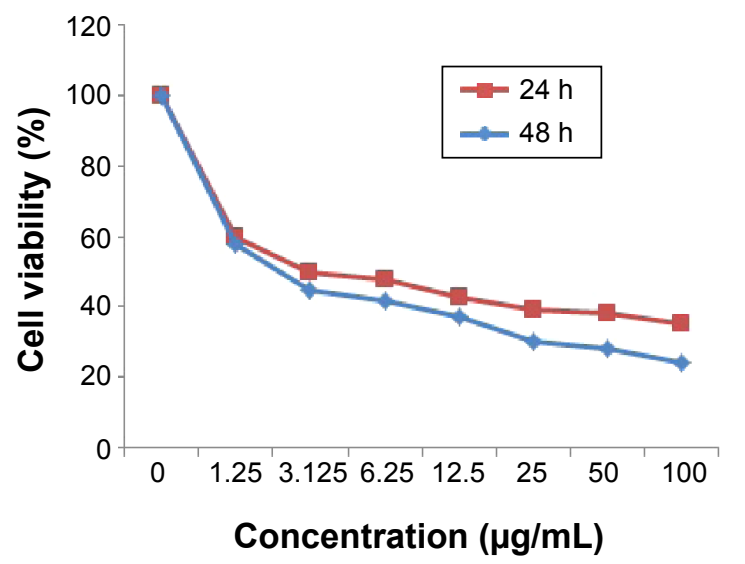

Figure 4 The cytotoxic effect of compound $\mathrm{Cl}$ on MCF-7 cells.

Notes: The $I_{50}$ value of agent at 24 and 48 hours against MCF-7 cells was determined to be $3.5 \pm 0.50$ and $2.5 \pm 0.50 \mu \mathrm{g} / \mathrm{mL}$, respectively. The data are shown as the mean $\pm S D(n=3)$.

Abbreviations: $\mathrm{Cl}$, compound I [N-(3,5-dichloro-2-oxidobenzylidene)-4-chlorobenzyhydrazidato] (o-methylbenzyl)aquatin(IV) chloride; h, hours; $\mathrm{IC}_{50}$, half maximal inhibitory concentration; SD, standard deviation. 
A

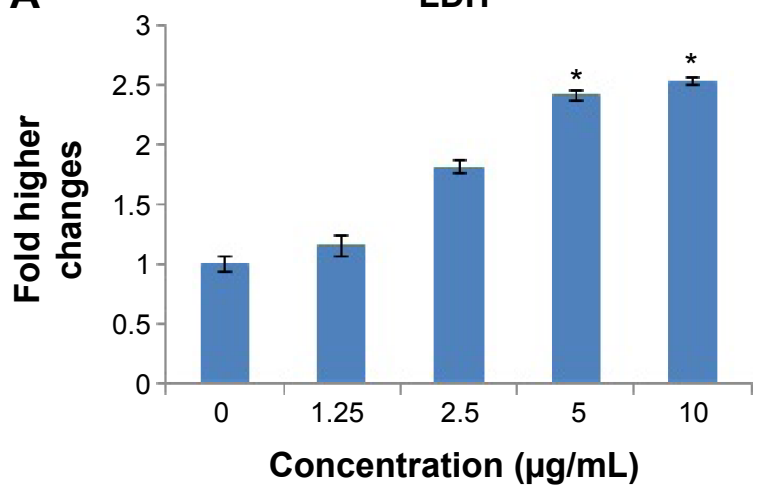

B
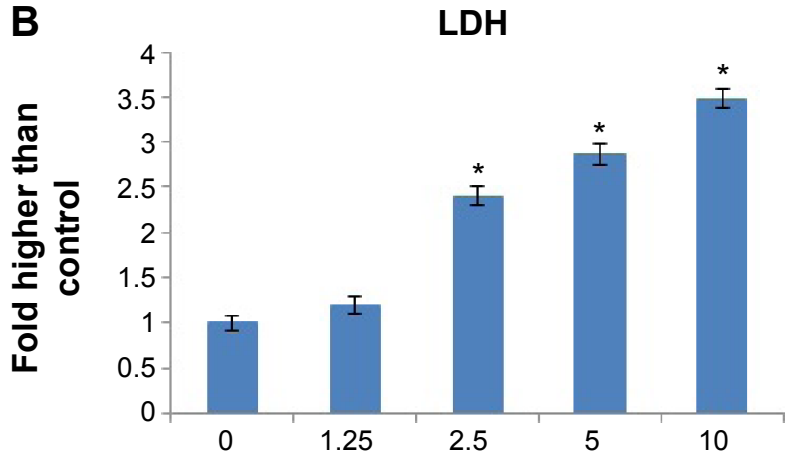

Concentration $(\mu \mathrm{g} / \mathrm{mL})$

Figure 5 Significant LDH release in the cell culture medium after exposure of MCF-7 cells to the $1.25,2.5,5$, and $10 \mu \mathrm{g} / \mathrm{mL}$ concentrations of benzyltin compound $\mathrm{Cl}$ for (A) 24 hours and (B) 48 hours.

Notes: Data are mean \pm SD and representative of three independent experiments. Each independent experiment was performed in triplicate for each treatment group. The statistical significance is expressed as $* P<0.05$.

Abbreviations: $\mathrm{Cl}$, compound I [N-(3,5-dichloro-2-oxidobenzylidene)-4-chlorobenzyhydrazidato](o-methylbenzyl)aquatin(IV) chloride; LDH, lactate dehydrogenase; SD, standard deviation.
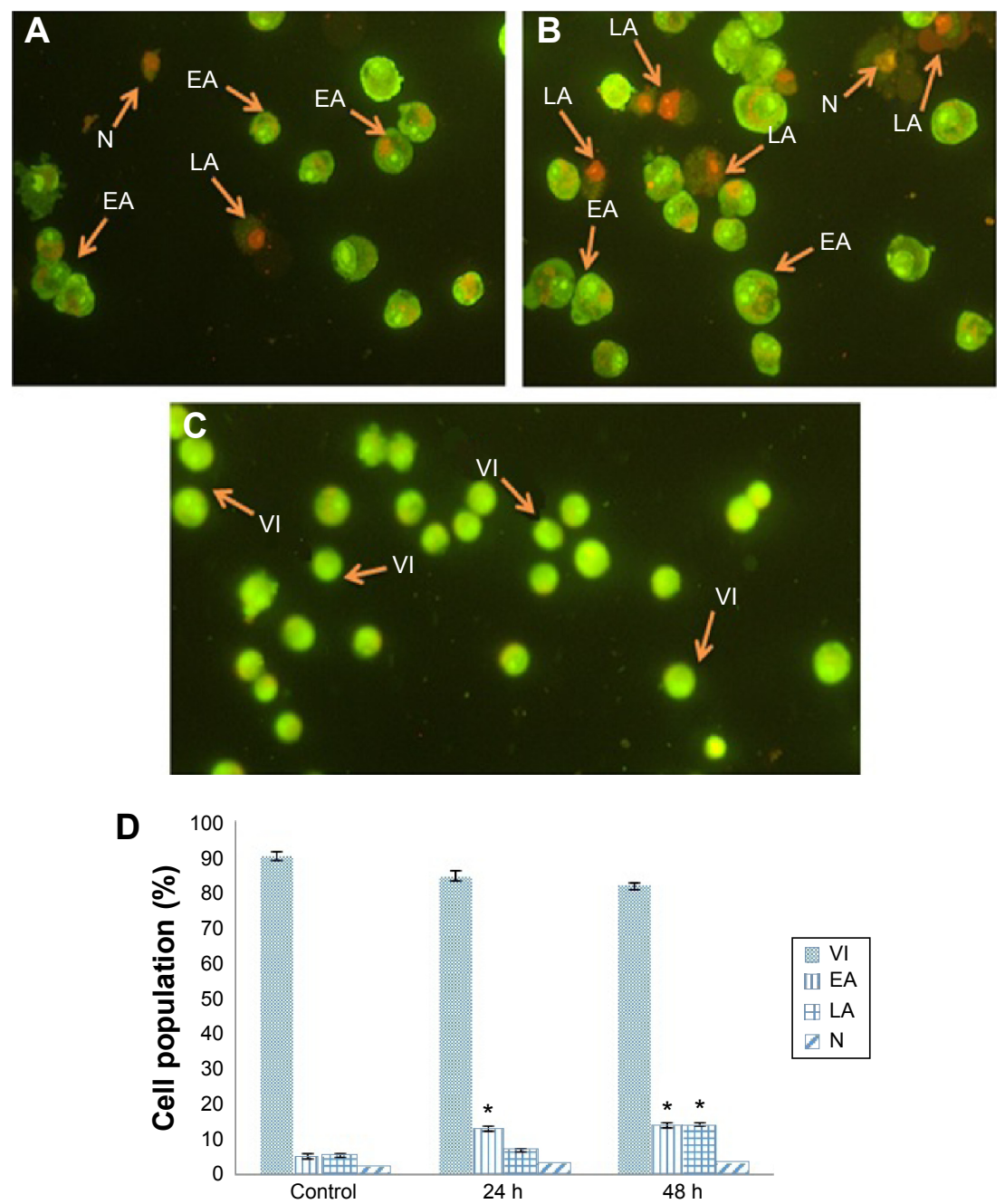

Figure 6 AO/PI staining of untreated MCF-7 cells and MCF-7 cells treated with IC 50 of compound Cl for 24 and 48 hours.

Notes: (A and B) Treated cells after 24 and 48 hours, respectively. (C) Untreated cells. (D) Percentages of viable, early apoptotic, late apoptotic, and necrotic cells. *Demonstrates significant difference $(P<0.05)$ compared with control.

Abbreviations: $\mathrm{AO}$, acridine orange; $\mathrm{Cl}$, compound I [N-(3,5-dichloro-2-oxidobenzylidene)-4-chlorobenzyhydrazidato](o-methylbenzyl)aquatin(IV) chloride; EA, early apoptotic cells; h, hours; $\mathrm{IC}_{50}$, half maximal inhibitory concentration; LA, late apoptotic cells; N, necrotic cells; Pl, propidium iodide; VI, viable cells. 

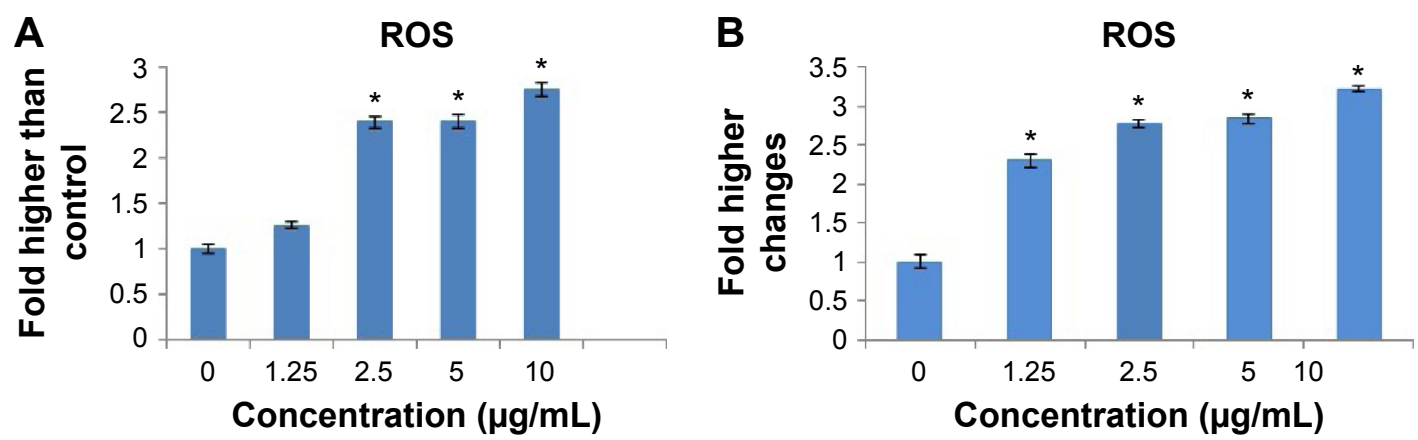

Figure 7 ROS generation in treated MCF-7 cells.

Notes: ROS generation as determined by DCFH-DA fluorescence intensity after $1.25,2.5,5$, and $10 \mu g / \mathrm{mL}$ of benzyltin compound $\mathrm{Cl}$ exposure at (A) 24 hours and (B) 48 hours. Data are mean \pm SD and representative of three independent experiments. Each independent experiment was performed in triplicate for each treatment group. The statistical significance is expressed as $* P<0.05$.

Abbreviations: $\mathrm{Cl}$, compound I [N-(3,5-dichloro-2-oxidobenzylidene)-4-chlorobenzyhydrazidato](o-methylbenzyl)aquatin(IV) chloride; DCFH-DA, 2',7'-dichlorofluorescein diacetate; ROS, reactive oxygen species; SD, standard deviation.

the percentage of late apoptotic cells was increased significantly after exposure of cells to agent $\mathrm{C} 1$ for 24 and 48 hours, while increase in the percentage of early apoptotic cells was significant only in cells treated for 24 hours.

\section{Measurement of ROS}

The normal cell metabolism of oxygen reduction to water leads to production of ROS molecules. Mitochondrial membrane disruption, apoptosis, and cell death have been proved to be related to oxidative stress due to generation of intracellular ROS. This alteration was assessed after 24 and 48 hours of treatment in MCF-7 cells using oxidation-sensitive fluorescent dye DCFH-DA. $\mathrm{H}_{2} \mathrm{O}_{2}$, which is a standard producer of ROS, was used as a positive control. As can be observed in Figure 7, there was a significant increasing trend in ROS production from negative control to positive control after treatment for both 24 and 48 hours. In addition, it is worth mentioning the higher twofold faster ROS generation at 24 hours with a $2.5 \mu \mathrm{g} / \mathrm{mL}$ concentration $\left(\mathrm{IC}_{50}\right)$ in comparison to negative control, where ROS production was at a basal level. The significant increase of ROS generation after 48 hours at a lower concentration of compound $\mathrm{C} 1$ than $\mathrm{IC}_{50}(1.25 \mu \mathrm{g} / \mathrm{mL})$ supports the high potential cytotoxicity of compound $\mathrm{C} 1$ through ROS burst, which suggests the stimulation of the mitochondrial-initiated events.

\section{Determination of mode of cell death by DNA laddering assay}

The DNA ladder, a form of DNA degradation, is acknowledged as a key biomedical pattern of apoptosis. Our results show that the internucleosomal fragmentation was pronounced in compound C1-treated MCF-7 samples. As can be observed in Figure 8, creation of the DNA ladder happened following exposure of cells to compound for 24, 48, and 72 hours. The positive control in Figure 8 demonstrates the ladder of the DNA.

\section{Discussion}

\section{Synthetic aspect}

The ligand behaves as a dibasic tridentate chelator, replacing the two anionic chloride moieties of di(o-methylbenzyl)

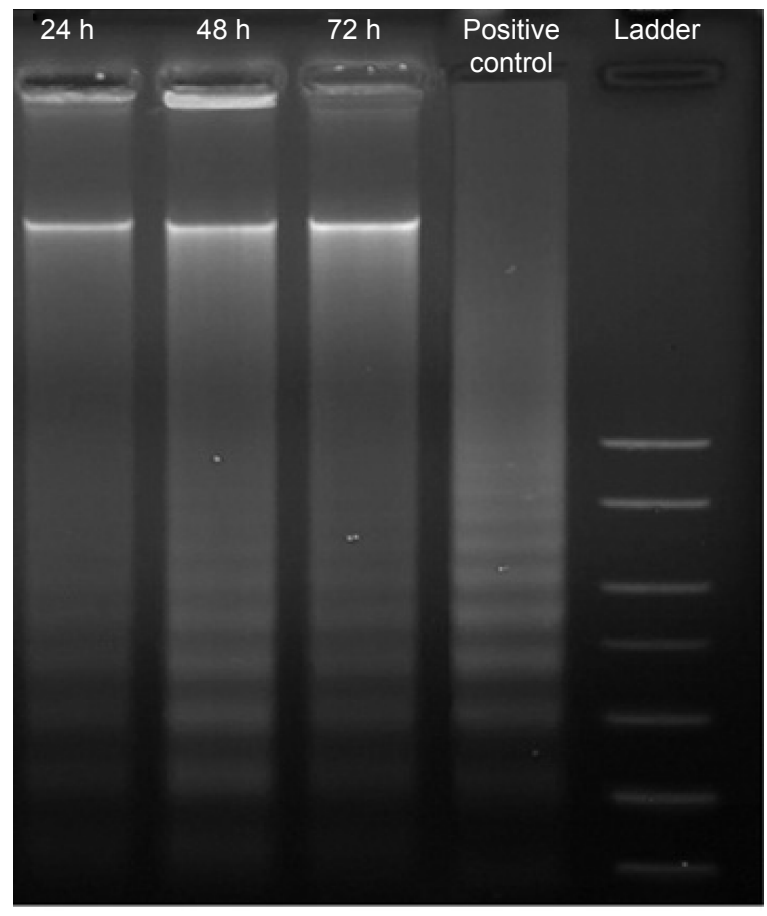

Figure 8 Agarose gel image of ladder formation.

Notes: MCF-7 cells were exposed to benzyltin compound $\mathrm{Cl}$ at $I \mathrm{C}_{50}$ for 24,48 , and 72 hours. DNA was extracted and fragmentation in DNA was assessed using electrophoresis and 1.5\% agarose gel. The occurrence of ladders for treated MCF-7 cells indicates apoptosis.

Abbreviations: $\mathrm{CI}$, compound I [N-(3,5-dichloro-2-oxidobenzylidene)-4-chlorobenzyhydrazidato](o-methylbenzyl)aquatin(IV) chloride; h, hours; ${ } C_{50}$, half maximal inhibitory concentration. 
tin dichloride and coordinated to the tin atom via the enolic oxygen, imino nitrogen, and phenolic oxygen atoms. The resulting substituted di(o-methylbenzyl)tin compound was subsequently converted to the six-coordinated monobenzyltin compound $\mathrm{C} 1$ upon reacting with $\mathrm{HCl}$, which was a byproduct in the reaction.

\section{Spectroscopic characterization}

The IR spectrum of the ligand $\mathrm{L}$ displayed characteristic bands of $v(\mathrm{C}=\mathrm{O})$ and $v(\mathrm{C}=\mathrm{N})$ at $1,656 \mathrm{~cm}^{-1}$ and $1,607 \mathrm{~cm}^{-1}$, respectively. The stretching frequencies of the phenolic $-\mathrm{OH}$ and - $\mathrm{NH}$ groups appeared as a strong envelope in the range of 3,500-3,200 $\mathrm{cm}^{-1} .{ }^{34}$ The $v(-\mathrm{OH})$ peak at $3,000 \mathrm{~cm}^{-1}$ disappeared in the spectrum of compound $\mathrm{C} 1$, indicating the deprotonation of the $\mathrm{OH}$ group and coordination of the phenolic oxygen atom to the tin center. ${ }^{34}$ The carbonyl stretching frequency, $v(\mathrm{C}=\mathrm{O})$ was found to have shifted from $1,656 \mathrm{~cm}^{-1}$ to $1,532 \mathrm{~cm}^{-1}$ due to the enolization of the carbonyl group to facilitate the formation of the second covalent $\mathrm{Sn}-\mathrm{O}$ bond. A strong band at $1,612 \mathrm{~cm}^{-1}$ is assigned to the $v(\mathrm{C}=\mathrm{N})$ stretching in the compound. It was also noted that the $v(\mathrm{C}=\mathrm{N})$ for the compound appeared at a lower frequency, supporting the fact that the ligand is also coordinated to the tin atom via the azomethine nitrogen. ${ }^{35}$ The lowering of the $\mathrm{C}=\mathrm{N}$ stretching frequencies in the compound was due to the reduction in the electron density of the azomethine nitrogen, which led to the weakening of the double bond.

The NMR chemical shifts for the aromatic protons and carbons were found to be within the expected range. The integration values were completely consistent with the chemical formula of the compounds. The ${ }^{1} \mathrm{H}$ NMR spectrum of $\mathrm{C} 1 \mathrm{did}$ not show any resonance signal for $\mathrm{O}-\mathrm{H}$ proton. However, the chemical shift for the azomethine proton of the ligand was observed as a sharp singlet at $8.52 \mathrm{ppm}$ and was found to have shifted to 8.89 ppm upon formation of the compound.

The ${ }^{1} \mathrm{H}$ NMR spectrum of $\mathrm{C} 1$ was also found to exhibit resonance signals characteristic of benzyl $-\mathrm{CH}_{2}$ protons at $3.14 \mathrm{ppm}$ with the expected intensity ratio as well as the aromatic protons of the benzyl moiety that resonate in the range of 7.05-7.34 ppm. The additional broad strong singlet at $\sim 3.40$ ppm was due to the coordinated water molecule.

The carbon skeletons of the compounds were identified by ${ }^{13} \mathrm{C}$ NMR in DMSO- $\mathrm{d}_{6}$. The ${ }^{13} \mathrm{C}$ NMR spectrum of the ligand and $\mathrm{C} 1$ displayed the expected carbon signals in all cases. In general, the spectrum of the compound showed a slight downfield shift for all the carbon resonances of the coordinated ligand, compared with those of the free ligand.
The ${ }^{13} \mathrm{C}$ NMR spectrum of the compound also showed a significant downfield shift of azomethine carbon resonances (158.7 ppm), compared with that of the free ligand (147 ppm). The downfield shift is attributed to the electron transfer from the ligand to the tin center, resulting in the azomethine carbon being deshielded. ${ }^{19}$ The resonance peaks for the aromatic carbon of the ligand were generally unaffected upon metal complexation.

${ }^{119} \mathrm{Sn}$ NMR spectroscopy has been a useful technique for structure elucidation and determining the nature of coordination of tin center in compounds. ${ }^{36}$ The ${ }^{119} \mathrm{Sn}$ NMR spectrum of $\mathrm{C} 1$ revealed a single signal at $-488 \mathrm{ppm}$, indicating that the six-coordinated solid state structure, as determined by $\mathrm{X}$-ray crystallography, is retained in solution. ${ }^{37}$

Compound $\mathrm{C} 1$ is a six-coordinated tin structure with a distorted octahedral geometry. The octahedral environment around the tin atom comprises a benzyl group and imino nitrogen, carbonyl oxygen, and hydroxyl oxygen atoms from the Schiff base ligand and a chloride anion. The sixth coordination site of the compound is occupied by a water molecule. The Schiff ligand behaves as a tridentate dianionic ligand and coordinated to the tin atom, forming five- and six-membered chelate rings, with the corresponding bite angles of $73^{\circ}$ and $84^{\circ}$, respectively. These bite angles are comparable to those reported earlier. ${ }^{34,38}$ The five-membered chelating ring in the compound was practically planar, with root mean square deviation from planarity of $0.0290 \AA$. The six-membered chelate ring, however, was slightly puckered, with a larger root mean square deviation of $0.1024 \AA$. The two chelating rings formed a dihedral angle of $6.76^{\circ}$. The root mean square deviation from the plane containing all non-H atoms in the Schiff base ligand was $0.1602 \AA$. The axial positions of $\mathrm{C} 1$ were occupied by two oxygen atoms, with the O1-Sn1-O2 angle substantially compressed from $180^{\circ}\left(158.19^{\circ}\right)$.

Apoptosis as a key pathway for regulating cell death is connected with numerous disorders, particularly cancer. ${ }^{39}$ Most advances applied in cancer treatment, such as chemotherapy and radiation therapy, are likely to be affected by the apoptotic properties of cells, hence anticancer studies have been largely focused on agents with a mechanism of action for targeting apoptotic pathways. ${ }^{40}$

MCF-7 is the most common breast cancer cell line and was originally isolated from a pleural effusion taken from a 69 -year-old woman with metastatic breast cancer. ${ }^{41}$ It is valuable for in vitro breast cancer studies because of several ideal characteristics particular to the mammary epithelium, including estrogen process and sensitivity to cytokeratin. ${ }^{41}$ In the present study, the cytotoxic effect of benzyltin 
compound $\mathrm{C} 1$ against MCF-7 cells was analyzed by MTT assay, which is based on the enzymatic reduction of MTT to insoluble formazan in viable cells. ${ }^{30}$ Our MTT results showed the significant inhibition effect of benzyltin compound $\mathrm{C} 1$ on MCF-7 cells after 48 hours' treatment with $\mathrm{IC}_{50} 2.5 \mu \mathrm{g} /$ $\mathrm{mL}$, which indicates the greater sensitivity of MCF-7 cells for this compound in comparison to other cancer cells. According to our results, it can be concluded that compound $\mathrm{C} 1$ has an effective antiproliferative effect against a broad range of cancerous cells. In addition, the high $\mathrm{IC}_{50}$ value for WRL-68 normal hepatic cells demonstrates the specific effect of compound for cancer cells. The cytotoxic effect of the compound $\mathrm{C} 1$ against MCF-7 cells was further established by LDH assay, which is based on release of the LDH enzyme to the culture medium after cell death. ${ }^{30}$ Noticeably higher LDH release in treated cells suggests the $\mathrm{C} 1$-induced growth inhibition occurred through influence on membrane integrity, which can happen through either apoptosis or necrosis. We also addressed some known molecular mechanisms of apoptosis, including morphological changes, ROS generation, and DNA fragmentation. We distinguished early apoptotic, late apoptotic, and necrotic cells in treated cells, by using $\mathrm{AO}$ and PI, which are the most common fluorescent dyes. In addition, in comparison with control, a significant growth in percentage of apoptotic cells was observed after treatment. The C1-treated MCF-7 cells revealed a significantly raised level of intracellular ROS in a concentration-dependent manner. A DNA laddering experiment was performed to further confirm the apoptotic properties of our agent. DNA fragmentation is a standard hallmark of cell death induced by ROS. ${ }^{29}$ The cells' chromosomal DNA remained undamaged in untreated cells; however, in the treated samples, chromosomal DNA was split into smaller DNA fragments known as ladders. These data suggest that compound $\mathrm{C} 1$-induced DNA fragmentation may be as a consequence of growth in ROS production after treatment. Therefore, the present study demonstrates that treatment with benzyltin compound $\mathrm{C} 1$ is capable of inducing cell death by an apoptotic process in human MCF-7 cells.

\section{Conclusion}

The monoorganotin Schiff base compound C1 was synthesized and characterized. The cell viability assay showed potential activity of $\mathrm{C} 1$ for breast cancer cell lines, and less activity for ovarian and prostate cancer cell lines. Furthermore, this compound triggered apoptosis in MCF-7 cells through the ability to cause DNA fragmentation. MCF-7 cells treated with $\mathrm{C} 1$ showed different stages of apoptosis, including early apoptosis and late apoptosis under fluorescent microscopy, and a significant increase in ROS production. Our findings reveal that benzyltin compound $\mathrm{C} 1$ can give rise to cell death via the apoptosis pathway in MCF-7 cells. However, additional studies are still required to more accurately explain the mechanism of this inhibition pathway for this compound.

\section{Acknowledgments}

The authors would like to express their utmost gratitude and appreciation for the University of Malaya Research Grant (RG084-13BIO) and Institute of Research Management and Monitoring (IPPP) grants (PG082-2013B, PG116-2014A, and PG126-2014A) for providing partial financial support to conduct this study.

\section{Disclosure}

The authors report no conflicts of interest in this work.

\section{References}

1. Alama A, Tasso B, Novelli F, Sparatore F. Organometallic compounds in oncology: implications of novel organotins as antitumor agents. Drug Discov Today. 2009;14(9-10):500-508.

2. Awang N, Kamaludin NF, Ghazali AR. Cytotoxic effect of organotin(IV) benzylisopropyldithiocarbamate compounds on Chang liver cell and hepatocarcinoma HepG2 cell. PakJ Biol Sci. 2011;14(15): 768-774.

3. Hadjikakou SK, Hadjiliadis N. Antiproliferative and anti-tumor activity of organotin compounds. Coord Chem Rev. 2009;253(1-2): 235-249.

4. Gielen M, Biesemans M, de Vos D, Willem R. Synthesis, characterization and in vitro antitumor activity of di- and triorganotin derivatives of polyoxa- and biologically relevant carboxylic acids. $J$ Inorg Biochem. 2000;79(1-4):139-145.

5. Gómez E, Contreras-Ordoñez G, Ramírez-Apan T. Synthesis, characterization and in vitro cytotoxicity of pentacoordinated Tin(IV) complexes derived from aminoalcohols. Chem Pharm Bull (Tokyo). 2006;54(1): $54-57$.

6. Cagnoli M, Alama A, Barbieri F, Novelli F, Bruzzo C, Sparatore F. Synthesis and biological activity of gold and tin compounds in ovarian cancer cells. Anticancer Drugs. 1998;9(7):603-610.

7. Lee SM, Mohd Ali H, Sim KS, Abdul Malek SN, Lo KM. Synthesis, characterization and biological activity of diorganotin complexes with $O N O$ terdentate Schiff base. Inorganica Chim Acta. 2013;406: 272-278.

8. Caruso F, Giomini M, Giuliani A, Rivarola E. Synthesis and spectroscopic studies (Mössbauer, IR and NMR) of $\left[\mathrm{R}_{2} \mathrm{SnCl}_{2}\right.$ bipym $](\mathrm{R}=$ butyl or phenyl) and the crystal and molecular structure of $\left[\mathrm{Ph}_{2} \mathrm{SnCl}_{2}\right.$ bipym]. J Organomet Chem. 1994;466(1-2):69-75.

9. Harada S, Hiromori Y, Nakamura S, et al. Structural basis for PPAR $\gamma$ transactivation by endocrine-disrupting organotin compounds. Sci Rep. 2015;5:8520.

10. Siddiqi ZA, Shahid M, Kumar S, Khalid M, Noor S. Synthesis, crystal structure and in vitro antitumor activity of carboxylate bridged dinuclear organotin(IV) complexes. J Organomet Chem. 2009;694(23): 3768-3774.

11. Thoonen SHL, Deelman B-J, van Koten G. Synthetic aspects of tetraorganotins and organotin(IV) halides. J Organomet Chem. 2004;689(13): 2145-2157.

12. Kizlink J. Structure-affected bioactivity of triorganotin compounds. Chemical Papers. 2001;55(1):53-57. 
13. Rehman W, Baloch MK, Badshah A. Synthesis, spectral characterization and bio-analysis of some organotin(IV) complexes. Eur J Med Chem. 2008;43(11):2380-2385.

14. Xanthopoulou MN, Hadjikakou SK, Hadjiliadis N, et al. Synthesis, structural characterization and in vitro cytotoxicity of organotin(IV) derivatives of heterocyclic thioamides, 2-mercaptobenzothiazole, 5-chloro-2-mercaptobenzothiazole, 3-methyl-2-mercaptobenzothiazole and 2-mercaptonicotinic acid. J Inorg Biochem. 2003;96(2-3): 425-434.

15. Shpakovsky DB, Banti CN, Beaulieu-Houle G, et al. Synthesis, structural characterization and in vitro inhibitory studies against human breast cancer of the bis-(2,6-di-tert-butylphenol)tin(IV) dichloride and its complexes. Dalton Trans. 2012;41(48):14568-14582.

16. Kumar S, Dhar DN, Saxena PN. Applications of metal complexes of Schiff bases-a review. J Sci Ind Res (India). 2009;68(3):181-187.

17. Pellerito C, Nagy L, Pellerito L, Szorcsik A. Biological activity studies on organotin(IV) ${ }^{n+}$ complexes and parent compounds. J Organomet Chem. 2006;691(8):1733-1747.

18. Iorns E, Drews-Elger K, Ward TM, et al. A new mouse model for the study of human breast cancer metastasis. PLoS One. 2012;7(10): e47995.

19. Olsson H. Cell of origin of breast cancer: an updated hypothesis merging epidemiological data with molecular biology. J Carcinog Mutagen 2013;4:139.

20. Hajrezaie M, Paydar M, Looi CY, et al. Apoptotic effect of novel Schiff based $\mathrm{CdCl} 2\left(\mathrm{C}_{14} \mathrm{H}_{21} \mathrm{~N}_{3} \mathrm{O}_{2}\right)$ complex is mediated via activation of the mitochondrial pathway in colon cancer cells. Sci Rep. 2015;5:90-97.

21. Marsh S, McLeod HL. Pharmacogenetics and oncology treatment for breast cancer. Expert Opin Pharmacother. 2007;8(2):119-127

22. Cárdenas M, Marder M, Blank VC, Roguin LP. Antitumor activity of some natural flavonoids and synthetic derivatives on various human and murine cancer cell lines. Bioorg Med Chem. 2006;14(9):2966-2971.

23. Mgbonyebi OP, Russo J, Russo IH. Antiproliferative effect of synthetic resveratrol on human breast epithelial cells. Int J Oncol. 1998;12(4): 865-869.

24. Elmore S. Apoptosis: A Review of Programmed Cell Death. Toxic Pathol. 2007;35(4):495-516.

25. Kennedy SG, Wagner AJ, Conzen SD, et al. The PI 3-kinase/Akt signaling pathway delivers an anti-apoptotic signal. Genes Dev. 1997;11(6): 701-713.

26. Jayakumar S, Haridass S, Krishnamurthy V. Anticancer activity of Punica granatum rind extracts against human lung cancer cell line. Asian Journal of Pharmaceutical and Clinical Research. 2012;5(Suppl 2): 204-210.

27. Simon HU, Haj-Yehia A, Levi-Schaffer F. Role of reactive oxygen species (ROS) in apoptosis induction. Apoptosis. 2000;5(5):415-418.
28. Evans MD, Dizdaroglu M, Cooke MS. Oxidative DNA damage and disease: induction, repair and significance. Mutat Res. 2004; 567(1):1-61.

29. Aryapour H, Riazi GH, Ahmadian S, Foroumadi A, Mahdavi M, Emami S. Induction of apoptosis through tubulin inhibition in human cancer cells by new chromene-based chalcones. Pharm Biol. 2012;50(12):1551-1560.

30. Rouhollahi E, Zorofchian Moghadamtousi Z, Paydar M, et al. Inhibitory effect of Curcuma purpurascens BI. rhizome on HT-29 colon cancer cells through mitochondrial-dependent apoptosis pathway. BMC Complem Altern Med. 2015;15:15.

31. Sisido K, Takeda Y, Kinugawa Z. Direct synthesis of organotin compounds. I. Di- and tribenzyltin chlorides. J Am Chem Soc. 1961;83(3):538-541.

32. Sheldrick GM. A short history of SHELX. Acta Crystallogr A. 2008; 64(Pt 1):112-122.

33. Barbour LJ. X-Seed - a software tool for supramolecular crystallography. Journal of Supramolecular Chemistry. 2001;1(4-6):189-191.

34. Dey DK, Dey SP, Lycka A, Rosair GM. Structure and spectroscopy of diorganotin(IV) complexes derived from $N^{\prime}$-(2-hydroxy3-methoxybenzylidene)benzohydrazide. Polyhedron. 2011;30(15): 2544-2549.

35. Shujah S, Zia-ur-Rehman, Muhammad N, Ali S, Khalid N, Tahir MN. New dimeric and supramolecular organotin(IV) complexes with a tridentate schiff base as potential biocidal agents. J Organomet Chem 2011;696(15-16):2772-2781.

36. Rehman W, Badshah A, Khan S, Tuyet le TA. Synthesis, characterization, antimicrobial and antitumor screening of some diorganotin(IV) complexes of 2-[(9H-Purin-6-ylimino)]-phenol. Eur J Med Chem. 2009;44(10):3981-3985.

37. Basu Baul TS, Mizar A, Song X, et al. Dibenzyltin(IV) complexes of the 5-[(E)-2-(aryl)-1-diazenyl]quinolin-8-olates: synthesis and an investigation of structures by X-ray diffraction, solution and solid-state tin NMR, ${ }^{119} \mathrm{Sn}$ Mössbauer and electrospray ionization MS. J Organomet Chem. 2006;691(12):2605-2613.

38. Hong M, Yin H-D, Chen S-W, Wang D-Q. Synthesis and structural characterization of organotin(IV) compounds derived from the selfassembly of hydrazone Schiff base series and various alkyltin salts. J Organomet Chem. 2010;695(5):653-662.

39. Salim LZ, Mohan S, Othman R, et al. Thymoquinone induces mitochondria-mediated apoptosis in acute lymphoblastic leukaemia in vitro. Molecules. 2013;18(9):11219-11240.

40. Edris AE. Anti-cancer properties of Nigella spp. essential oils and their major constituents, thymoquinone and beta-elemene. Curr Clin Pharmacol. 2009;4(1):43-46.

41. Levenson AS, Jordan VC. MCF-7: the first hormone-responsive breast cancer cell line. Cancer Res. 1997;57(15):3071-3078.

\section{Publish your work in this journal}

Drug Design, Development and Therapy is an international, peerreviewed open-access journal that spans the spectrum of drug design and development through to clinical applications. Clinical outcomes, patient safety, and programs for the development and effective, safe, and sustained use of medicines are a feature of the journal, which

\section{Dovepress}

has also been accepted for indexing on PubMed Central. The manuscript management system is completely online and includes a very quick and fair peer-review system, which is all easy to use. Visit http://www.dovepress.com/testimonials.php to read real quotes from published authors. 